\title{
Studies of polypropylene membrane fouling during microfiltration of broth with Citrobacter freundii bacteria
}

\author{
Marek Gryta*, Marta Waszak, Maria Tomaszewska \\ West Pomeranian University of Technology, Szczecin, Institute of Inorganic Technology and Environment Engineering, \\ ul. Pułaskiego 10, 70-322 Szczecin, Poland \\ "Corresponding author: e-mail: Marek.Gryta@zut.edu.pl
}

\begin{abstract}
In this work a fouling study of polypropylene membranes used for microfiltration of glycerol solutions fermented by Citrobacter freundii bacteria was presented. The permeate free of $C$. freundii bacteria and having a turbidity in the range of $0.72-1.46$ NTU was obtained. However, the initial permeate flux $\left(100-110 \mathrm{~L} / \mathrm{m}^{2} \mathrm{~h}\right.$ at $30 \mathrm{kPa}$ of transmembrane pressure) was decreased 3-5 fold during $2-3 \mathrm{~h}$ of process duration. The performed scanning electron microscope observations confirmed that the filtered bacteria and suspensions present in the broth formed a cake layer on the membrane surface. A method of periodical module rinsing was used for restriction of the fouling influence on a flux decline. Rinsing with water removed most of the bacteria from the membrane surface, but did not permit to restore the initial permeate flux. It was confirmed that the irreversible fouling was dominated during broth filtration. The formed deposit was removed using a $1 \mathrm{wt} \%$ solution of sodium hydroxide as a rinsing solution.
\end{abstract}

Keywords: microfiltration, fouling, glycerol fermentation, 1,3-propanediol.

\section{INTRODUCTION}

Microfiltration (MF) has been widely used on the industrial scale since the beginning of the 20th' century and is currently applied in many fields of industry such as pharmaceutical, biotechnology and food industries ${ }^{1}$. The MF process is utilized for the purification and sterilization of various biological solutions, including fermentation broths. The separation of microorganism cells from the fermentation broth is a very important stage in the recovery of fermentation products. Bacteria which were not retained by membranes could initiate a biofouling of the MF membranes on the permeate side as well as on the feed side of downstream nanofiltration (NF) or reverse osmosis (RO) membranes in a MF-NF/RO systems ${ }^{1-3}$ or in a MF-pervaporation installation ${ }^{4}$. Therefore, the production of sterile MF permeate is crucial for broth separation by integrated downstream processes ${ }^{5}$.

It was observed, that a rapid flux decline occurred in the first few minutes of membrane filtration of bacterial suspensions ${ }^{3,6}$. A particle deposition at the membrane surface (fouling) is commonly considered as one of the main factors responsible for the decrease of the filtration rate with time in MF process. Moreover, it is accepted that the dissolved substances such as proteins, polysaccharides and polyphenols are involved in the fouling process. In the case of broth filtration, biofouling can be initiated by bacterial adhesion to the membrane surface caused by nonspecific adsorption (e.g., through hydrophobic interaction) ${ }^{7}$.

The flux decline caused by fouling can be reduced using backflush procedures and chemical cleaning steps, but these operations are time consuming and adding up mechanical and chemical stress to the filtration devices resulting in a loss of capacity and efficiency of such equipment ${ }^{8,9}$. Therefore, the research of low-fouling membrane materials are performed ${ }^{7,10-14}$. It was revealed, that significantly higher fluxes and lower fouling was obtained during a wine filtration for polypropylene membranes (PP) than that for the membranes made from polyethersulfone, both having the pore size equal to $0.2 \mu \mathrm{m}^{10}$. Moreover, the PP membranes appears to be more resistant to fouling during membrane distillation (MD) of glycerol solutions fermented by bacteria ${ }^{15}$.

A cleaning operation is not completely efficient or may be aggressive for the membranes in several cases ${ }^{7}$. Chemical cleaning, usually with aggressive solutions, is generally applied to hydraulically irreversible foulants. The chemical agents, particularly oxidants, are also used for disinfection to maintain the system free of microorganisms. The chemically resistance membranes made from highly hydrophobic polymers, such as poly tetrafluoroethylene (PTFE) or PP, should be used in these cases. However, the hydrophobic membranes are more liable to fouling ${ }^{7}$, therefore, ceramic membranes are proposed for biotechnology and food industry ${ }^{16}$. Due to their excellent chemical, thermal and mechanical stability ceramic membranes represent a very promising alternative to the polymer filter systems ${ }^{5,9,12,14}$.

The production of biofuels, such as diester (biodiesel), generates glycerol as a main by-product. The utilization of a crude glycerol to produce 1,3-propanediol (1,3-PD) by biological methods provides an area of opportunity, where it would be possible to capitalize on the surplus of waste glycerol ${ }^{17-19}$. The fermentation conditions, e.g. with Citrobacter freundii bacteria, that enable the maximum concentration of 1,3-PD are accompanied by inhibition phenomenon, notably by the fermentation products, such as diols and carboxylic acids ${ }^{20-22}$. A fed-batch culture is commonly used in the microbial fermentation to achieve a high cell density because a substrate limitation or inhibition can be avoided by maintaining the medium substrate concentration at a relatively constant level during the cultivation ${ }^{5,15}$.

The inhibition phenomenon can be restricted when the metabolites are selectively removed from the broth. This can be achieved by using the integrated membrane processes, such as NF/MD system ${ }^{23}$. Moreover, the microbiological processes are associated with the generation of the considerable amounts of diluted effluents from the bioreactors. In the integrated separation processes, the NF can be used to provide economic advantages not 
only to pre-concentrate these solutions before the next evaporation step, but also to recycle the process water ${ }^{24}$.

Citrobacter freundii are long rod-shaped bacteria typically $1-5 \mu \mathrm{m}$ in length ${ }^{25-27}$. The MF process with ceramic tubular membrane (pore diameter $0.14 \mu \mathrm{m}$, TAMI, France) was carried out as a pre-treatment stage before NF separation of broths with $C$. freundii bacteria $^{5}$. However, the retention of bacteria was not complete, and the MF permeate contained over $10^{3}-10^{4}$ cells, whereas bacteria concentration in the feed was at a level of $10^{11}$. These bacteria were retained when the PTFE membrane $(0.2 \mu \mathrm{m}$, Millipore $)$ was applied ${ }^{28}$. It was found that a type of membrane material and the cell-wall flexibility triggers the transfer of the bacteria through the membranes, when the pores are smaller in size than the cell ${ }^{2}{ }^{29}$. However, a significant fouling was observed due to a high hydrophobocity of $\mathrm{PTFE}^{28}$.

A lower hydrophobocity has a polypropylene, thus the PP membranes were used in this work for MF of broth with $C$. freundii bacteria, which was applied for 1,3-PD syntheses from glycerol. The permeate quality and the intensity of flux decline and fouling during the long-term MF studies was analyzed.

\section{EXPERIMENTAL}

The MF studies were carried out using the polypropylene capillary membranes (Accurel PP S6/2, Membrana $\mathrm{GmbH}$, Germany). The external and internal diameters of the membranes amounted to $2.6 \mathrm{~mm}$ and $1.8 \mathrm{~mm}$, respectively. The nominal and maximum diameters of the pores were $0.2 \mu \mathrm{m}$ and $0.6 \mu \mathrm{m}$, respectively, and the open porosity was $73 \%$ (manufacture data). These values are in a good agreement with experimental data ${ }^{30}$. The four capillary membranes were assembled in a MF1 module with $1.16 \mathrm{~m}$ length and the internal area equal to $0.026 \mathrm{~m}^{2}$. The MF1 module was chemically cleaned during MF studies. Therefore, additional two modules with the same membranes, length $1.18 \mathrm{~m}$ (MF2) and $0.35 \mathrm{~m}$ (MF3), were applied to obtain the membrane samples used in SEM studies of fouling layer deposited on the membrane surface.

The experimental set-up used for cross-flow MF was presented in Figure 1. During the MF process the feed flowed inside the capillaries (lumen side) and a transmembrane pressure (TMP) equal to $30 \mathrm{kPa}$ was applied. A peristaltic pump was used, and the volume flow velocity of the feed was $6 \pm 0.2 \mathrm{ml} / \mathrm{s}$. The initial feed volume was about $1.5 \mathrm{~L}$, and it was reduced 3-4 fold during the MF process. The MF modules were constructed without an external shell and during the MF studies the module was assembled inside the permeate tank.

The actual values of the maximal permeate flux were determined using the distilled water as a reference solution. After completing the studies of broth separation, the membranes in the MF1 module were subjected to the chemical cleaning (TMP $\approx 0$ and flow velocity 0.6 $\mathrm{m} / \mathrm{s}$ ). The cleaning procedure was as follows: rinsing the installation with distilled water (10 min), cleaning with an aqueous solution $(1.5 \mathrm{~g} / \mathrm{L})$ of alkaline cleaning agent P3-ultrasil 11 (ECOLAB, Poland) for $30 \mathrm{~min}$, followed by rinsing (three times) with water over $10 \mathrm{~min}$. In the

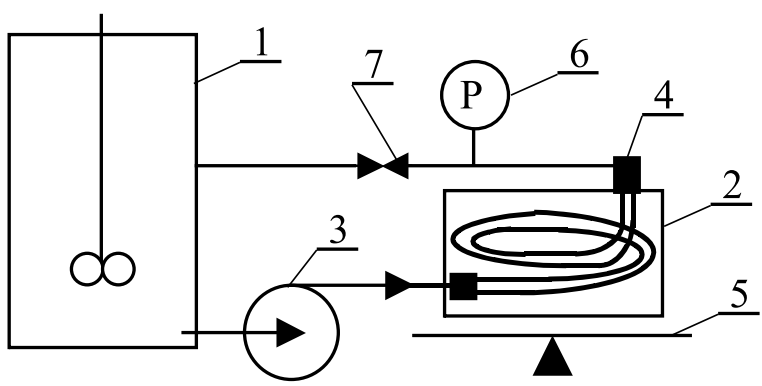

Figure 1. MF experimental set-up. 1 - bioreactor (feed tank), 2 - permeate tank, 3 - pump, 4 - MF module, 5 balance, 6 - manometer, 7 - valve

second variant of cleaning procedure, a $1 \mathrm{wt} \% \mathrm{NaOH}$ solution was used instead P3-ultrasil 11.

The broths for MF studies were taken from batch fermentations, which were conducted in a LiFlusGX bioreactor (Biotron Inc., Korea). Fresh cultures of Citrobacter freundii were inoculated under sterile conditions in the bioreactor (bacteria culture comprised $5 \%$ of the total reactor volume). The medium for the fermentation process of glycerol $(20$ or $40 \mathrm{~g} / \mathrm{L})$ also contained: $3.4 \mathrm{~g}$ of $\mathrm{K}_{2} \mathrm{HPO}_{4}, 1.3 \mathrm{~g}$ of $\mathrm{KH}_{2} \mathrm{PO}_{4}, 2.0 \mathrm{~g}$ of $\left(\mathrm{NH}_{4}\right)_{2} \mathrm{SO}_{4}, 0.4 \mathrm{~g}$ of $\mathrm{MgSO}_{4} \cdot 7 \mathrm{H}_{2} \mathrm{O}, 0.01 \mathrm{~g}$ of $\mathrm{CaCl}_{2} \cdot 2 \mathrm{H}_{2} \mathrm{O}, 0.004 \mathrm{~g}$ of $\mathrm{CoCl}_{2} \cdot 6 \mathrm{H}_{2} \mathrm{O}, 2.0 \mathrm{~g}$ of yeast extract, $2.5 \mathrm{~g}$ of peptone $\mathrm{K}$ and $1.5 \mathrm{~g}$ of meat extract in $1 \mathrm{~L}$ of distilled water. About $24 \mathrm{~h}$ fermentation processes were performed with agitation at $150 \pm 5 \mathrm{~min}^{-1}$ and the incubation temperature equal to $30^{\circ} \mathrm{C}$. The $\mathrm{pH}$ value was maintained at 7.0 by automatic additions of $5 \mathrm{M} \mathrm{NaOH}$. The composition of obtained broths was presented in Table 1. Two cycles of MF studies with MF1 module were carried out. In the first (series S1-S6), the broths obtained during the fermentation of solutions contained $40 \mathrm{~g}$ glycerol/L were used as a feed. In the second cycle (series S7-S10) the fermented solutions contained initially $20 \mathrm{~g}$ glycerol/L.

The bacteria concentration was estimated by a series of broths dilution prepared in $\mathrm{NaCl}$ solution (0.9\%) and the obtained samples were placed on the MRS agar (BTL, Poland). The plates were incubated for $24 \mathrm{~h}$ at $303 \mathrm{~K}$ and the colony-forming units (CFUs/ml) were then counted. This experiment was repeated three times.

The degree of bacteria retention by used MF membranes was investigated by collecting of the permeate samples after 10, 30, 60 and $90 \mathrm{~min}$ of MF process duration. At the beginning of MF process, a permeate tank and the external surface of the membranes located in this tank were rinsed by a $75 \mathrm{wt} \%$ solution of ethanol (sterilization).

A biomass concentration was also determined using a dry mass method and the turbidity measurements. A Hach 2100AN IS Turbidimeter was used to measure turbidity (NTU scale). For determination of dry mass concentration a sample of $0.05 \mathrm{~L}$ of broth, was centrifuged (4000 rpm, centrifuge MPW-350R, Med-Instruments, USA). A temperature of biomass drying was about $363 \mathrm{~K}$.

The concentrations of glycerol, 1,3-PD and the organic acids were determined by a high performance liquid chromatography (HPLC) using an UlitiMate 3000 apparatus (Dionex, USA) with refractometer detector R1-101 (Shodex) and a column Aminex HPX-87H (BIO RAD, USA) with HyperREZ XP H+ Guard (Thermo Scien- 
Table 1. The composition of post-fermented solutions subjected to separation by MF (series S1-S10)

\begin{tabular}{|l|c|c|c|c|c|c|c|}
\hline Component, [g/L] & $\mathrm{S} 1$ & $\mathrm{~S} 3$ & $\mathrm{~S} 4$ & $\mathrm{~S} 5$ & $\mathrm{~S} 7$ & $\mathrm{~S} 9$ & $\mathrm{~S} 10$ \\
\hline $1,3 \mathrm{PD}$ & 20.1 & 20.5 & 18.9 & 19.9 & 11.4 & 9.98 & 10.1 \\
\hline Glycerol & 0.33 & 0.46 & 1.2 & 0.57 & 0.95 & 0.35 & 0.25 \\
\hline Lactic acid & 0.78 & 1.68 & 3.7 & 2.85 & 2.9 & 1.48 & 1.88 \\
\hline Acetic acid & 6.34 & 6.25 & 4.9 & 5.75 & 2.95 & 1.66 & 5.48 \\
\hline Succinic acid & 1.83 & 1.63 & 1.37 & 1.53 & 2.2 & 1.13 & 1.47 \\
\hline $\mathrm{Cl}^{-}$ & 0.038 & 0.037 & 0.074 & 0.081 & 0.041 & 0.029 & 0.044 \\
\hline $\mathrm{PO}_{4}{ }^{2-}$ & 1.83 & 1.92 & 2.31 & 2.57 & 2.01 & 2.29 & 1.99 \\
\hline $\mathrm{SO}_{4}{ }^{2-}$ & 1.28 & 1.34 & 1.46 & 1.73 & 1.34 & 1.63 & 1.52 \\
\hline $\mathrm{NH}_{4}^{+}$ & 0.35 & 0.42 & 0.57 & 0.55 & 0.45 & 0.66 & 0.55 \\
\hline $\mathrm{K}^{+}$ & 1.21 & 1.11 & 1.64 & 1.27 & 1.12 & 1.26 & 1.49 \\
\hline $\mathrm{Na}^{+}$ & 3.86 & 4.32 & 4.97 & 4.72 & 1.38 & 2.61 & 2.52 \\
\hline $\mathrm{Ca}^{2+}$ & 0.012 & 0.11 & 0.059 & 0.047 & 0.012 & 0.03 & 0.015 \\
\hline $\mathrm{Mg}^{2+}$ & 0.032 & 0.021 & 0.028 & 0.021 & 0.031 & 0.028 & 0.031 \\
\hline $\mathrm{pH}$ & 6.89 & 7.01 & 6.92 & 6.94 & 6.91 & 7.02 & 6.94 \\
\hline
\end{tabular}

tific, USA), through which a $\mathrm{H}_{2} \mathrm{SO}_{4}$ solution $(0.005 \mathrm{M})$ flowed $(0.6 \mathrm{~mL} / \mathrm{min})$.

The anion and cation concentrations were determined using the ion chromatography method with conductivity detector (850 Professional IC, Herisau Metrohm, Switzerland). The separation of anions was achieved on a $1.7 \mathrm{~mm} \times 3.5 \mathrm{~mm}$ Metrosep RP guard column in series with a $250 \mathrm{~mm} \times 4.0 \mathrm{~mm}$ Metrohm A Supp5250 analytical column. An analytical column $150 \mathrm{~mm} \times$ $4.0 \mathrm{~mm}$ Metrosep C2-150 was used for cations separation. The $\mathrm{pH}$ value was measured with a $6 \mathrm{P}$ Ultrameter (Myron L Company).

A membrane morphology and deposit compositions were studied using scanning electron microscope (SEM) coupled with the energy dispersion spectrometry (EDS). The samples for cross-sectional observations were prepared by fracture of the capillary membranes in liquid nitrogen. All samples were sputter coated with palladium.

An analysis of distribution of bacteria particle size and other suspended solids, contained in the fermentation broth, was performed by a laser scattering particle size distribution analyzer, LA-950V2 (Horiba), using a light refractive index equal to 1.4 .

Hydrophilicity/hydrophobicity of the PP membranes were determined by dynamic contact angle measurements based on the Wilhelmy plate method. The measurements were carried out using a Sigma 701 microbalance (KSV Instrument, Ltd., Finland) integrated with a PC for automatic control and data acquisition.

\section{RESULTS AND DISCUSSION}

\section{Membrane characteristic}

A morphology of used capillary membranes was analysed based on the SEM observations. The Accurel PP membranes are symmetrical and they are characterized by a sponge-like structure (Fig. 2). A wall thickness of used Accurel PP membranes was equal to $400 \mu \mathrm{m}$. A size of the surface pores located on the lumen side was found to be uniform (usually about $1-2 \mu \mathrm{m}$ ) and was slightly larger than that inside the wall (Fig. 2C). The larger pores can facilitate the penetration of biomass into the pore interior (internal fouling). However, the pores inside the wall are significant smaller, and according to manufacture's data the particles larger than 0.2 $\mu \mathrm{m}$ should be retained.
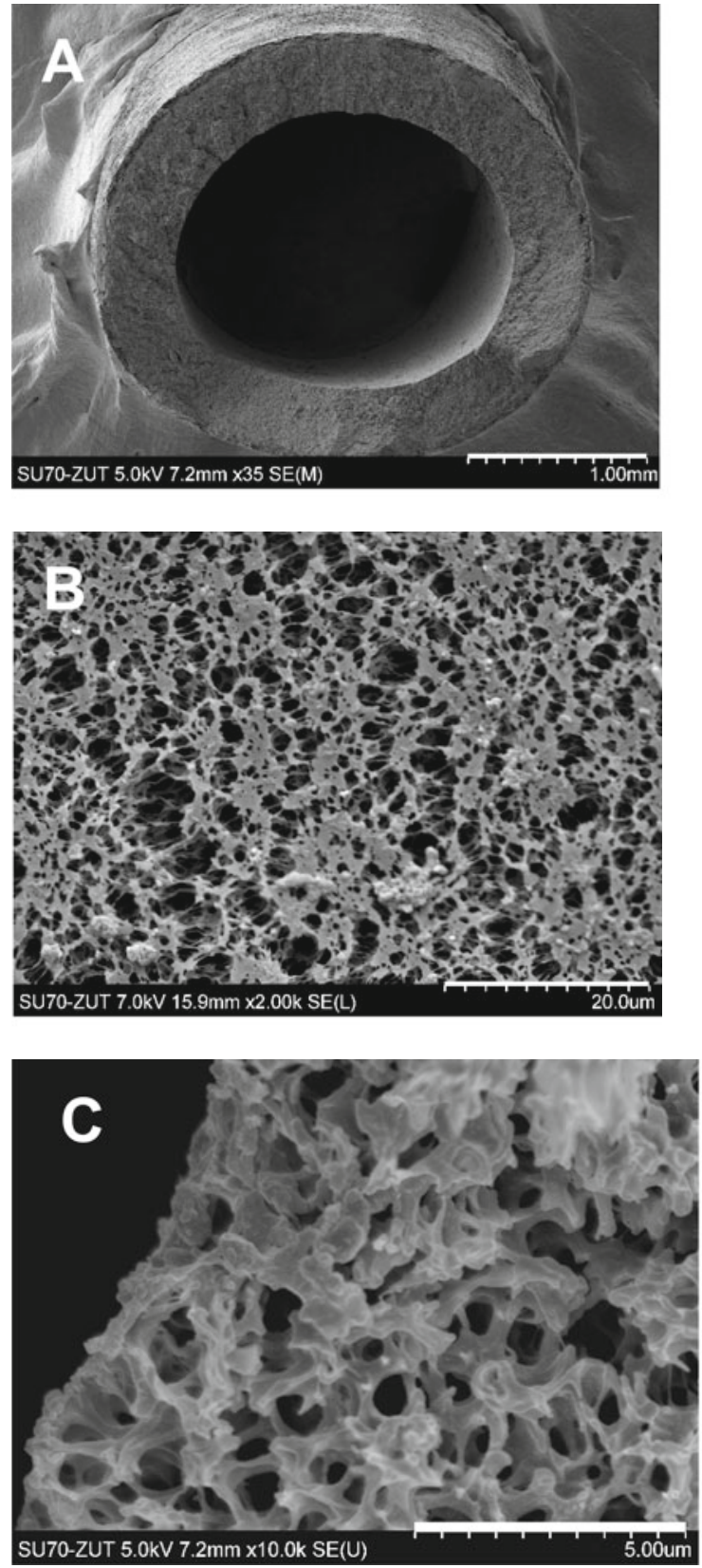

Figure 2. SEM images of Accurel PP S6/2 membrane. A) membrane cross-section, B) surface - lumen side, C) cross-section - area close to lumen side

Generally, it was observed that the permeate fluxes obtained during membrane separation of real solutions are significantly lower than that for pure water, due to a deposition of foulants on the membrane surfaces ${ }^{31-33}$. 
Therefore, for the evaluation of fouling influence on a reduction of the membrane permeability, the initial stable maximum permeate flux (distilled water as a feed) should be at first estimated. The studies of contact angle of Accurel PP S6/2 membranes demonstrated, that a value $101 \mathrm{deg}$ was obtained for distilled water. The water entry pressure for used Accurel PP S6/2 dry membranes is about $0.2-0.3 \mathrm{MPa}^{34}$, thus for applied TMP $=0.03 \mathrm{MPa}$ water cannot flow through their pores. Therefore, at the beginning of the MF study, the membranes were wetted with ethanol, which was replaced with distilled water after $10-15 \mathrm{~min}$ of the MF process duration. This procedure was repeated three times and after a few days of MF process (feed - distilled water) the stabilization of the maximum permeate flux at a level of 100-120 $\mathrm{L} / \mathrm{m}^{2} \mathrm{~h}$ was achieved. Similar results were also obtained for the MF2 and MF3 modules.

\section{Cross-flow MF process of broths}

The influence of fermentation parameters on the efficiency of both 1,3 PD production and broth downstream separation by NF process was presented in our previous work $^{35}$. These studies demonstrated that a decrease of the initial glycerol concentration in the broth to a level of 20-40 g/L allows to increase the effectiveness of batch fermentation. Therefore, in this work the fermentations were carried out with glycerol concentration equal to 20 or $40 \mathrm{~g} / \mathrm{L}$. A composition of several exemplary post-fermented solutions applied for the filtration by MF process was presented in Table 1.

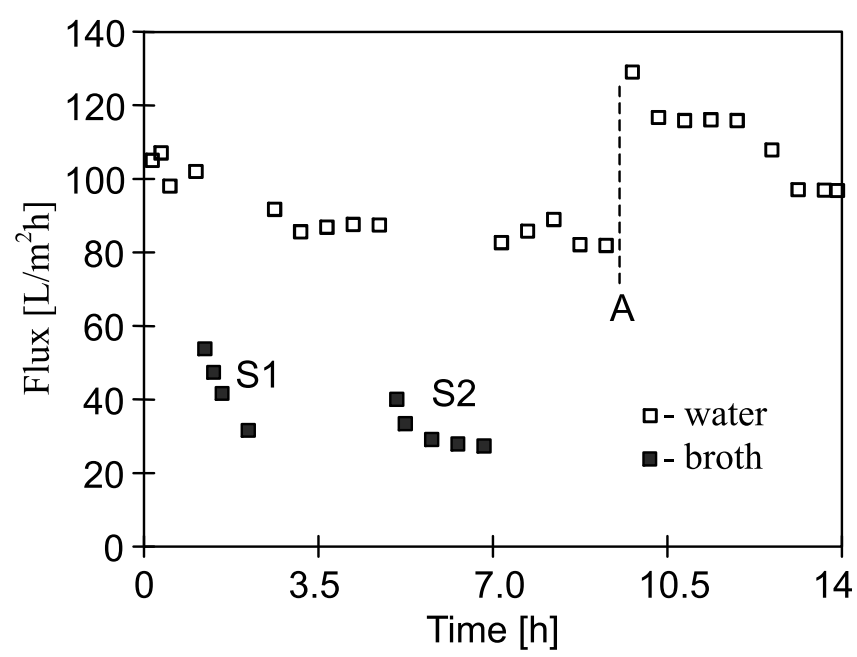

Figure 3. The influence of process time on the MF permeate flux. Point A - membranes soaked in distilled water for 82 h. Module MF1. Feed - broth $40 \mathrm{~g} / \mathrm{L}$

In the first cycle of MF studies the broths produced during the fermentation of solution contained $40 \mathrm{~g}$ glycerol/L (denoted as "broth $40 \mathrm{~g} / \mathrm{L}$ ") were used. The studies confirmed that a significant decrease of the permeate flux was observed (Fig. 3), probably due to a membrane fouling. During the first $2 \mathrm{~h}$ of process operation the permeate flux decreased from 110 to $27-31 \mathrm{~L} / \mathrm{m}^{2} \mathrm{~h}$. Similar results were also obtained for the MF separation of other broths ${ }^{36,37}$. Most probably, the formation of cake layer has a dominant effect on the flux decline. After each MF series, the broth was removed and the module MF1 was rinsed two or three times with a new portion of distilled water, which increased the permeate flux (Fig. 3 - water after MF series). The module was immersed in distilled water through the night break, which provided additional cleaning. A large increase of the maximum permeate flux was obtained when the module was soaked in distilled water during consecutive $82 \mathrm{~h}$ (Fig. 3 - point A). The application of only water for module rinsing will be very comfortable in the case when the MF module is connected with bioreactor. The chemicals used for membrane cleaning are usually toxic for bacteria, and after a module rinsing a large volume of water should be used for their removal from MF module before broth filtration.

The possibility of applications of MF module rinsing with water exists in the case of batch fermentation. The results of MF process carried out in such a way are shown in Figure 4. Unfortunately, a slow systematic decrease of the permeate flux was observed, which indicated that even module was rinsing for a long time, did not permit to remove all the deposits formed on the membrane surface (irreversible fouling).

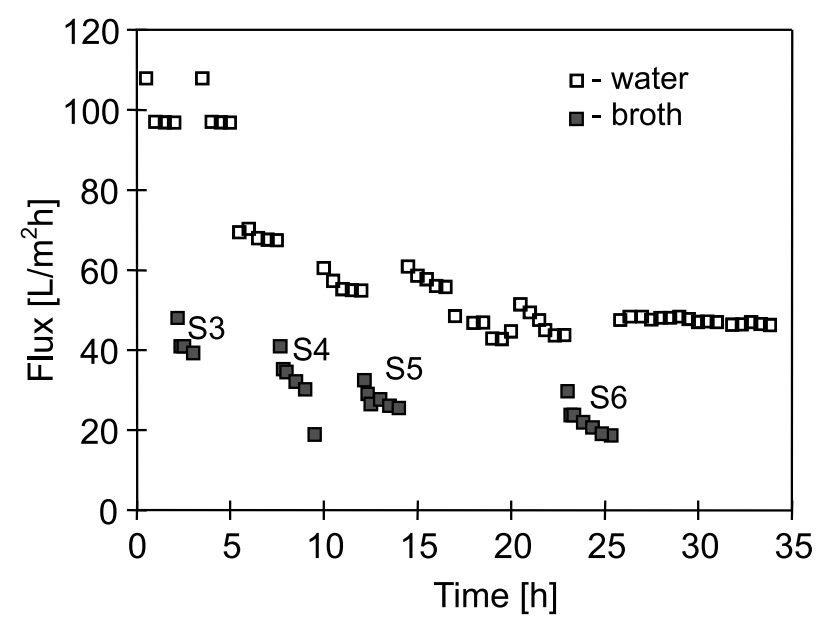

Figure 4. The changes of permeate flux during MF process of post-fermented solutions. Module MF1 periodically rinsed with water. Feed - broth $40 \mathrm{~g} / \mathrm{L}$

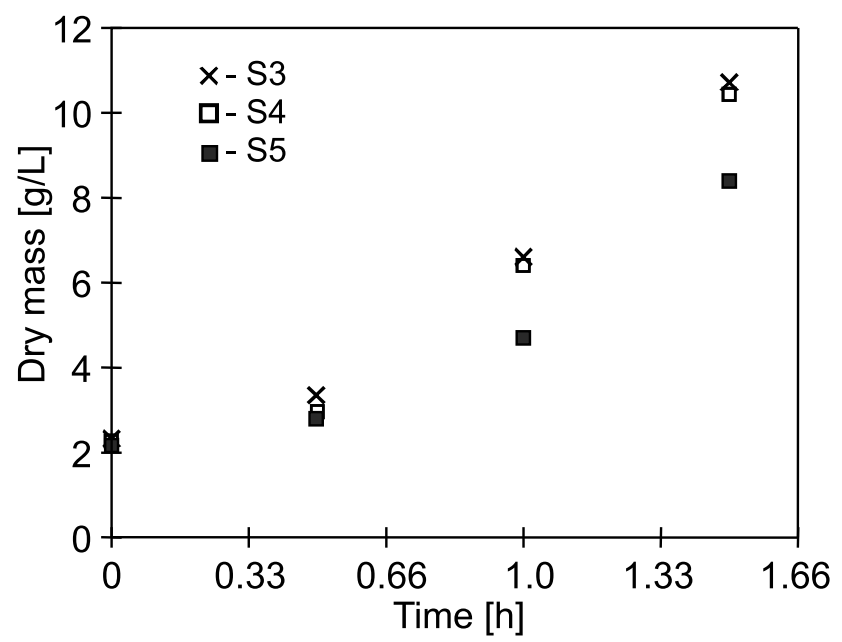

Figure 5. The changes of biomass concentration in the feed (dry mass) during batch mode of MF process. Module MF1. Feed - broth $40 \mathrm{~g} / \mathrm{L}$

The initial concentration of the broths used in the studies amounted to $2.2-2.32 \mathrm{~g} / \mathrm{L}$ of dry biomass and it was increased to $8.5-10.7 \mathrm{~g} / \mathrm{L}$ during the MF process realized in a batch mode (Fig. 5). The final biomass concentration decreases with MF series, which resulted 
from flux decrease due to a fouling progress. However, the flux stabilization (Fig. 4) confirmed that the fouling rate is not linearly proportional to the foulant concentration $^{38}$. In the cross-flow MF the most of the deposits is formed on the membranes at the filtration beginning, and the thickness of cake layer is stabilized due to a shear and hydraulic forces. Therefore, a rapid flux decline was observed during the first 20-30 min of each performed MF series, and subsequently this decline was stabilized.

The measurements of feed and permeate turbidity demonstrated a high degree of retention of suspended matter by used MF membrane (Fig. 6). Depending on the initial feed concentration the concentration of feed proceeded with a different rate and the NTU value of the feed was changed in the range from 2200 to 7700 NTU. For S1 and S2 series the permeate turbidity increased from 3 to 6 NTU, where the feed turbidity increases to 7700 NTU. For the next series the permeate turbidity was stabilized at a level of 0.72-1.46 NTU in each of these cases. These results indicate that a fouling layer formed on the membrane surface enhanced the separation effectiveness.

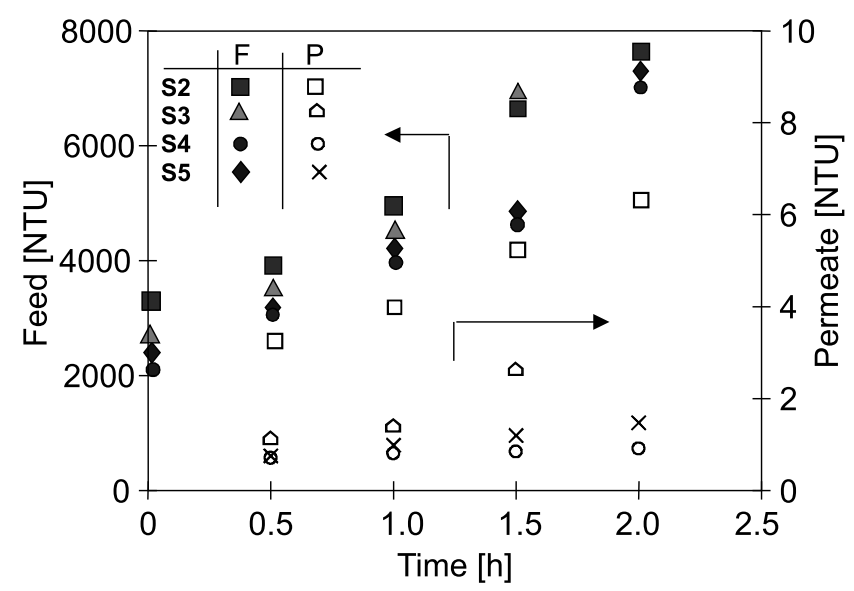

Figure 6. The influence of process time on the turbidity (NTU) of feed and permeate for consecutive series of performed MF studies. $\mathrm{F}$ - feed (closed symbols), $\mathrm{P}$ - permeate (open symbols). Module MF1. Feed - broth $40 \mathrm{~g} / \mathrm{L}$

The studies of particle sizes distributions together with bacteria dispersed in the broth were presented in Figure 7. These studies demonstrated that the smallest detected particles had a dimension of $0.5 \mu \mathrm{m}$. These dimensions are slightly smaller than the magnitude of the largest pores $(0.6 \mu \mathrm{m})$ given by the manufacturers of Accurel PP S6/2 membranes. For this reason, a fraction of the smallest particles may pass through the largest pores. However, the obtained low values of the MF permeate turbidity (Fig. 6) indicates that most of the cells and colloidal particles was reject by used membranes.

It was demonstrated in other works, that a small amount of bacteria may be transferred into the permeate even when their dimensions are 2-3 times larger than the pore size in the membrane ${ }^{2}$. The degree of bacteria rejection was estimated based on the plate method (CFU). In the post-fermented solutions, the concentration of Citrobacter freundii bacteria amounted to $9.7-11 \log \mathrm{CFU} / \mathrm{ml}$. The degree of bacteria retention was studied by collecting the permeate samples several times during a series S3-S5. The presence of bacteria in the permeate was not found in any case. Such a good

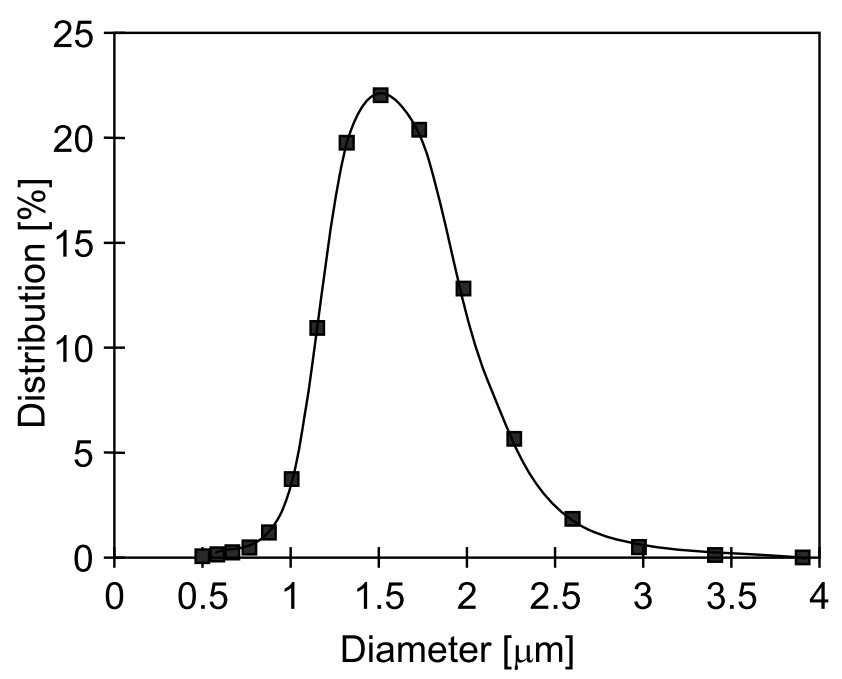

Figure 7. Distribution of particle size measured in the postfermented solution. Glycerol initial concentration in the broth $40 \mathrm{~g} / \mathrm{L}$

retention of bacteria most probably resulted from the formation of filter cake on the membrane surface, which can limit the possibility of bacteria penetration into the membrane pores and permeate.

In the second part of this work the post-fermented solutions, obtained by fermentation of the broth containing $20 \mathrm{~g} / \mathrm{L}$ of glycerol (denoted as "broth $20 \mathrm{~g} / \mathrm{L}$ "), were used for the investigations of MF process. The concentration of biomass in this case was about $0.9-1.2 \mathrm{~g} / \mathrm{L}$ (in case of broth $40 \mathrm{~g} / \mathrm{L}$ it was $2.2-2.3 \mathrm{~g} / \mathrm{L}$ ) and the living bacteria were at a level of 9.3-10.1 log CFU.

The MF studies revealed that in spite of a lower biomass concentration, the permeate flux obtained during broths filtration (series S7-S10) was also significantly lower than that for distilled water (Fig. 8). Moreover, the permeate fluxes were stabilized at a level of 20 $\mathrm{L} / \mathrm{m}^{2} \mathrm{~h}$ during series S7-S10, similarly as was obtained for series S6 (Fig. 4). This indicated, that the significant differences in the intensity of membrane fouling were not obtained in the studied range of biomass concentration (0.9-10 g/L). A significant increase of the maximum permeate flux (Fig. 8, point B) from 50 to $86 \mathrm{~L} / \mathrm{m}^{2} \mathrm{~h}$ was obtained after a week interval in $\mathrm{MF}$ process, during which the membranes were soaked in distilled water. However, the permeate flux during the MF process of broth (series S9) was only slightly larger than that from previous S8 series. Most probably during such a long interruption in the MF process, the deposit was only loosen (but not removed) which reduced the flow resistance. A confirmation of this conclusion can be the final results (Fig. 8, after $32 \mathrm{~h}$ ), which was obtained during five consecutive days of rinsing the MF1 module with water. Although, the duration of membrane' contact with water was similar, the flux did not increase because the deposit was compressed every day by the used transmembrane pressure $(0.03 \mathrm{MPa})$.

In the next part of studies the MF process of broth $20 \mathrm{~g} / \mathrm{L}$ was repeated for a module with new membranes (module MF2). In this case the permeate flux for broth was two times larger (Fig. 9) than that presented in Figure 8 for module MF1. However, a distribution of measurement points in Figure 9 was similar to that presented in Figure 3, which were obtained during MF of 


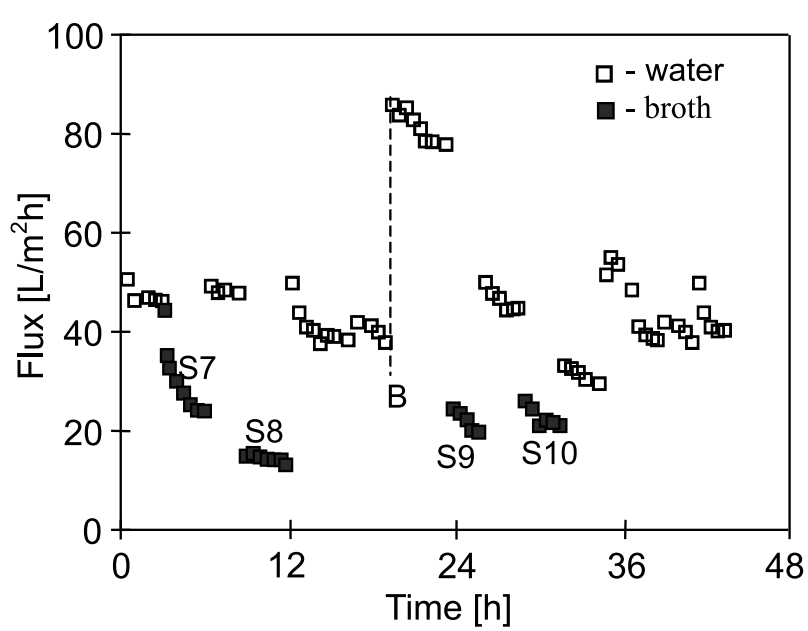

Figure 8. The changes of permeate flux during MF process of post-fermented solutions. Point B - membranes soaked in distilled water for a week. Module MF1. Feed - broth $20 \mathrm{~g} / \mathrm{L}$

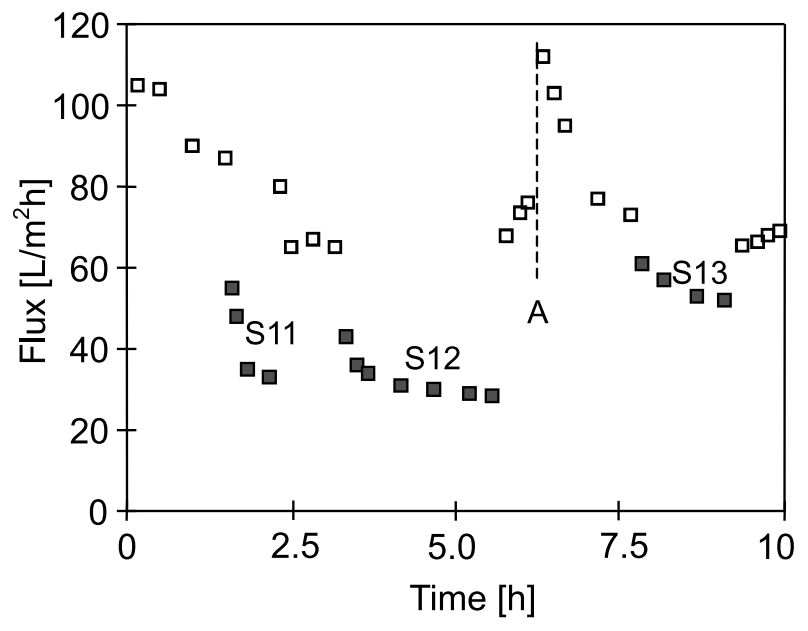

Figure 9. The changes of permeate flux during MF process of post-fermented solutions. Point A - membranes $76 \mathrm{~h}$ soaked in distilled water. Feed - broth $40 \mathrm{~g} / \mathrm{L}$. Module MF2 - new membranes

broth containing two times more of biomass. The result of this comparison confirms a previous conclusion, that a similar effect of fouling on a reduction of MF process efficiency was obtained for both kinds of examined broths (20 and $40 \mathrm{~g}$ of glycerol/L).

\section{Studies of membrane fouling}

The SEM observations revealed that a layer of deposit was formed on the membrane surfaces during MF process (Fig. 10). Thus, a decline of the permeate flux observed during presented studies of MF process mainly resulted from fouling. This result is similar to those obtained for other investigations of broth separation ${ }^{2,23}$. The deposits formed on the membrane surface can be generally divided into two groups. The deposits, which can be removed by rinsing a module with water (reversible fouling) belong to the first group while the second group include the deposits, which were not removed by rinsing with water (irreversible fouling $)^{38,39}$.

The samples for SEM studies of the fouling layer were taken from MF2 and MF3 modules, and different images of the membrane surfaces were observed. A module MF3 was used for three MF series, after which only a short

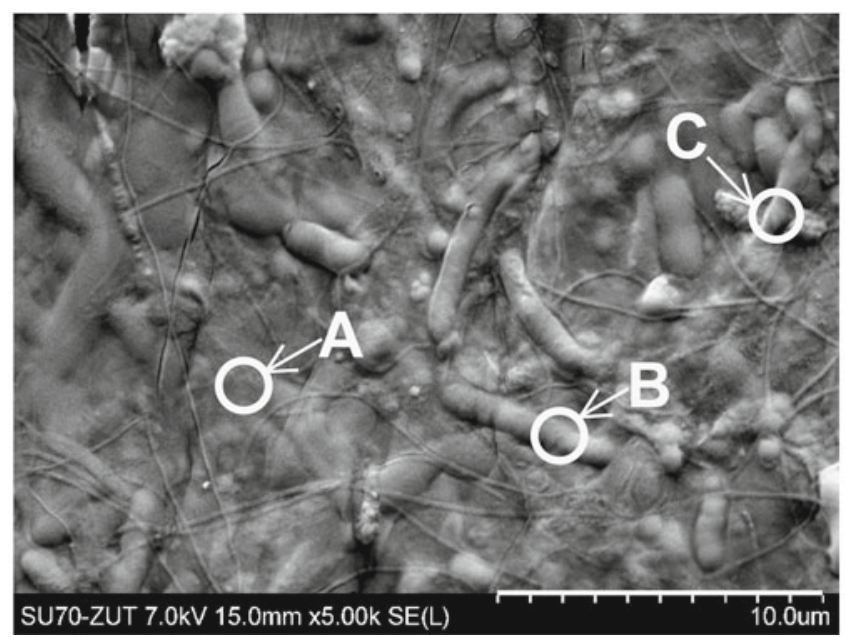

Figure 10. SEM image of deposit layer formed on the membrane surface in MF3 module. Broth only flushed by water from module. Membrane surface without deposit - Figure 2B

time of water rinsing was applied for broth removal from both the module and membrane surfaces. In this case, a continuous amorphous layer of deposit covered the entire membrane surface; moreover, a large amount of bacterial cells was observed on the membrane surface (Fig. 10). All the surface pores (showed in Fig. 2B) were covered by deposit, therefore, the membrane permeability was reduced.

Citrobacter freundii bacteria occur in the form of rods, which have most frequently a dimension of $2-5 \mu \mathrm{m}$ on the surface of tested samples. However, it is not easy to distinguish bacteria from other deposits with a similar shape. To differentiate from these shapes, it can be useful to utilize the results of SEM-EDS point analyses. The results of this analysis were presented in Table 2 . In the places without the bacteria (Fig. 10, point A), the SEM-EDS analysis indicated mainly carbon and a small amount of oxygen and Si. In the place occupied by bacteria (Fig. 10, points B and C), the SEM-EDS revealed beside carbon also a large amount of $\mathrm{N}$ and $\mathrm{O}$, and smaller amounts of $\mathrm{Mg}, \mathrm{Ca}$, and $\mathrm{K}$. These are the elements, which are included in the composition of compounds forming a wall of bacteria cell. This allows to assume, that the rod objects observed on the precipitate surface constitute bacteria.

The changes of the permeate flux obtained for MF2 module was presented in Figure 9. This module was operated similarly to MF1 module, and a long time rinsing with water between the MF series was applied (opposite to the MF3 module). The SEM observations demonstrated, that the membrane surface in the MF2 module contained less deposits. This module, similarly as MF1 module, had a length close to $1.2 \mathrm{~m}$. It was found, that a larger amount of deposit was formed at the module inlet (Fig. 11). The presence of rod-like shapes, which were previously prescribed to $C$. freundii bacteria (Fig. 10), practically was not observed on the membrane surfaces in MF2 module. However, numerous cavities can be observed, which is characteristic for the etched surfaces. This can indicate, that an intensive rinsing of MF2 module with water removed the majority of deposit, also including bacteria contained in this deposit. This fact was confirmed by the results of SEM-EDS analysis. It was detected mainly $\mathrm{C}$ and $\mathrm{O}$ in the deposit, as well as 
Table 2. The results of SEM-EDS analysis presented in percentage content of elements detected in the places indicated in Figures 10,11 and 12

\begin{tabular}{|c|c|c|c|c|c|c|c|c|}
\hline Point & C & $\mathrm{N}$ & $\mathrm{O}$ & $\mathrm{Mg}$ & $\mathrm{Si}$ & $\mathrm{K}$ & $\mathrm{Ca}$ & $\mathrm{Fe}$ \\
\hline Figure 10-A & 60.51 & - & 5.25 & - & 1.05 & - & - & - \\
\hline Figure $10-\mathrm{B}$ & 37.25 & 9.36 & 24.38 & 0.23 & 1.80 & 0.68 & 0.35 & - \\
\hline Figure $10-C$ & 35.36 & 11.93 & 31.88 & 0.47 & 0.88 & 1.11 & 0.35 & - \\
\hline Figure 11-A & 48.77 & - & 8.26 & 0.14 & 2.71 & - & - & - \\
\hline Figure 12-A & 28.54 & 6.16 & 34.87 & 0.23 & 3.29 & 0.77 & - & - \\
\hline Figure 12-B & 35.42 & - & 31.86 & 0.37 & 7.73 & 1.82 & - & 0.95 \\
\hline
\end{tabular}

small amounts of $\mathrm{Mg}$ and $\mathrm{Si}$ (Table 2, point Fig. 11-A). The obtained results indicate that the main reason of irreversible fouling during the broth filtration will not be a deposition of bacteria, but adsorptive organic fouling. It is widely accepted that the organic fouling is mainly caused by organic macromolecules such as soluble microbial products, extracellular polymeric substances (EPS) and possibly other substances resulting from cell lysis or lost during a cell synthesis ${ }^{39}$.

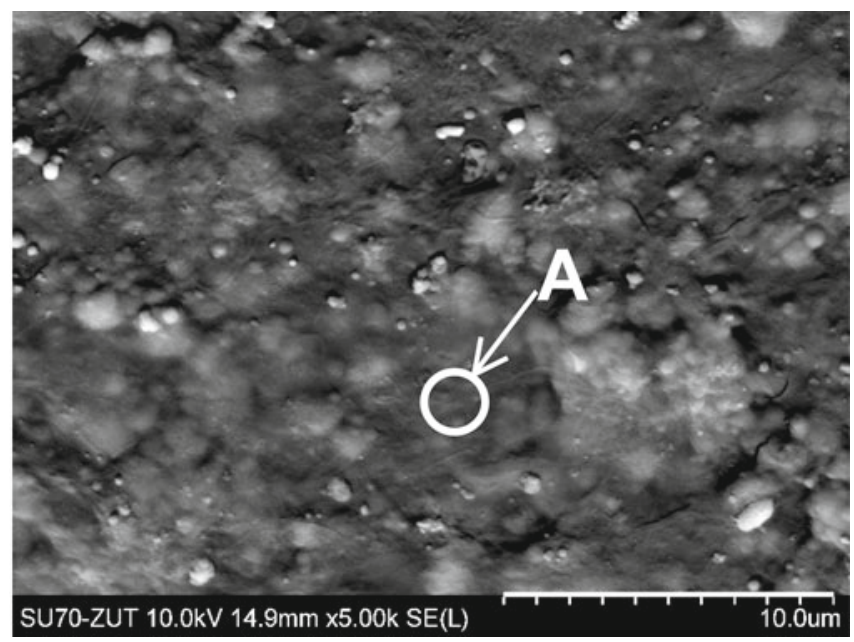

Figure 11. SEM image of deposit formed on the membrane surface in MF2 module during MF process of broths (broth 20 $\mathrm{g} / \mathrm{L})$. Sample taken $15 \mathrm{~cm}$ from the module inlet

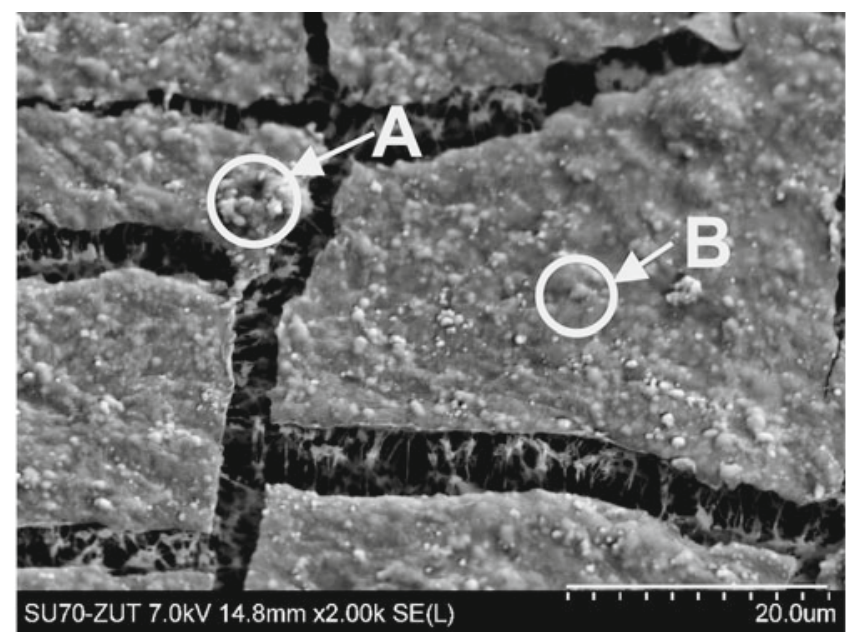

Figure 12. SEM image of deposit formed on the membrane surface in MF2 module during MF process of broths. Membrane sample taken $20 \mathrm{~cm}$ from the module outlet

A deposit in the vicinity of the module outlet also covered the entire surface of membranes, but it was fractured (Fig. 12). A fracture structure was formed most probably due to a sample drying, which indicates that the deposit was definitely thinner than that formed at the module inlet. The formed fractures exposed the pore surface.
The SEM observations of these pores revealed, that their interior did not contain contaminants and filtrated bacteria (Fig. 13). This confirms a conclusion, that a filter cake formed on the surface facilitated the retention of cells. In a few places spherical shapes (diameter 2-3 $\mu \mathrm{m}$ ) were observed on the deposit surface, which collapsed most probably due to drying of membrane sample. In this case, a composition of SEM-EDS analysis (Table 2, Fig. 12-A) confirmed the presence of cells. Numerous smaller spherical shapes with a diameter below $1 \mu \mathrm{m}$, visible in Figure 12, did not contain the nitrogen, which rather preclude that they were bacteria. However, significant amounts of $\mathrm{O}$ and $\mathrm{Si}$ and small amounts of $\mathrm{Fe}$ found in its composition (Table 2, Fig. 12-B), indicated for sparingly soluble deposits of silicates.

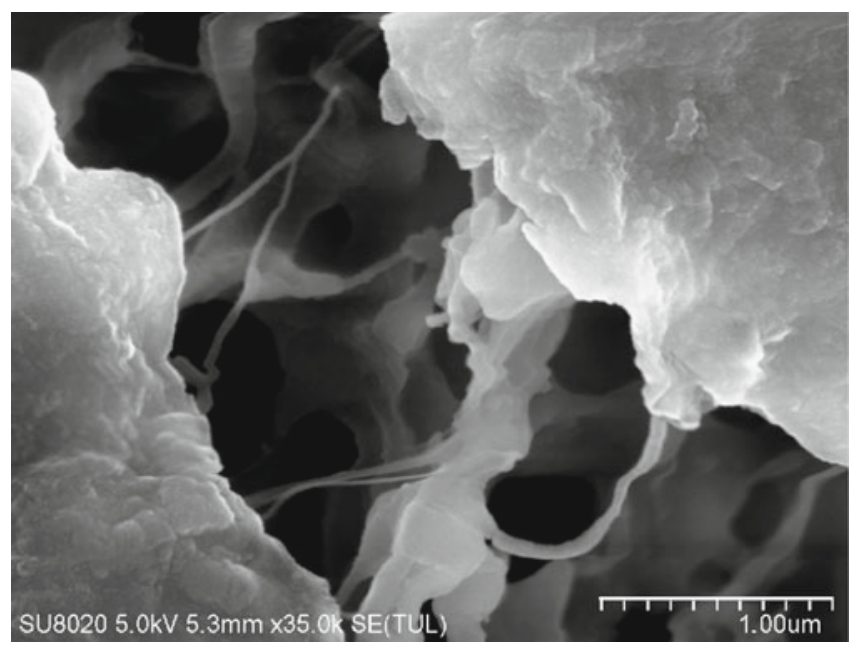

Figure 13. SEM image of the interior of pores located inside the factures presented in Figure 12

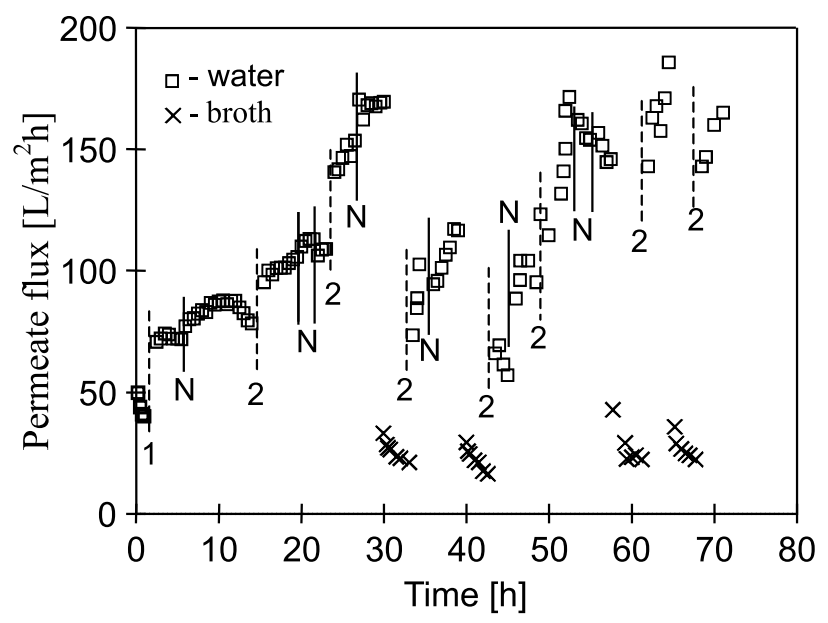

Figure 14. The changes of the permeate flux during chemical cleaning of MF1 module. Points: N - overnight break, 1 - P3ultrasil $11,2-1 \% \mathrm{NaOH}$ 
The results of SEM observations obtained for membranes from MF2 and MF3 modules confirmed that a significantly smaller amount of foulants deposited on the membrane surfaces when a module was long-time rinsed with water. Because not all the deposit was removed, a periodical chemical cleaning of membrane should be applied. In the first step, the MF1 module was rinsed with P3-ultrasil 11 solution for $30 \mathrm{~min}$, and an increase of the permeate flux from 40 to $72 \mathrm{~L} / \mathrm{m}^{2} \mathrm{~h}$ was obtained (Fig. 14). The used solutions of P3-ultrasil 11 beside other components contained $\mathrm{NaOH}$. For used in this work broth, the UF membrane was effective cleaned when a $1 \mathrm{wt} \% \mathrm{NaOH}$ was used ${ }^{5,28}$. Therefore, this rinsing agent was used also in this studies, and the initial permeate flux, about $110-113 \mathrm{~L} / \mathrm{m}^{2} \mathrm{~h}$, was restored (Fig. 14). The repetition of module rinsing with $\mathrm{NaOH}$ solution caused that the flux increased to $167 \mathrm{~L} / \mathrm{m}^{2} \mathrm{~h}$. The effectiveness of $\mathrm{NaOH}$ solutions applied for chemical cleaning of the membranes, which had been used for the separation of post-fermentation solutions, was also demonstrated in other works, 10, 12. The SEM observations confirmed that used $\mathrm{NaOH}$ solutions almost completely removed the deposits from the membrane surface. However, also in this case during broth filtration the permeate flux at a level of 30-20 L/m $\mathrm{m}^{2} \mathrm{~h}$ was obtained (Fig. 14, data from $55 \mathrm{~h}$ ). Thus, the removed of irreversible fouling layer not caused a significant increase the efficiency of broth filtration. Moreover, the SEM observations revealed that the pores edges, compared to membranes non rinsed with $\mathrm{NaOH}$ (Figs. 2B and 13), were changed (Fig. 15). On the pore edges can be observed the "etching effect", probably due to a PP degradation processes.

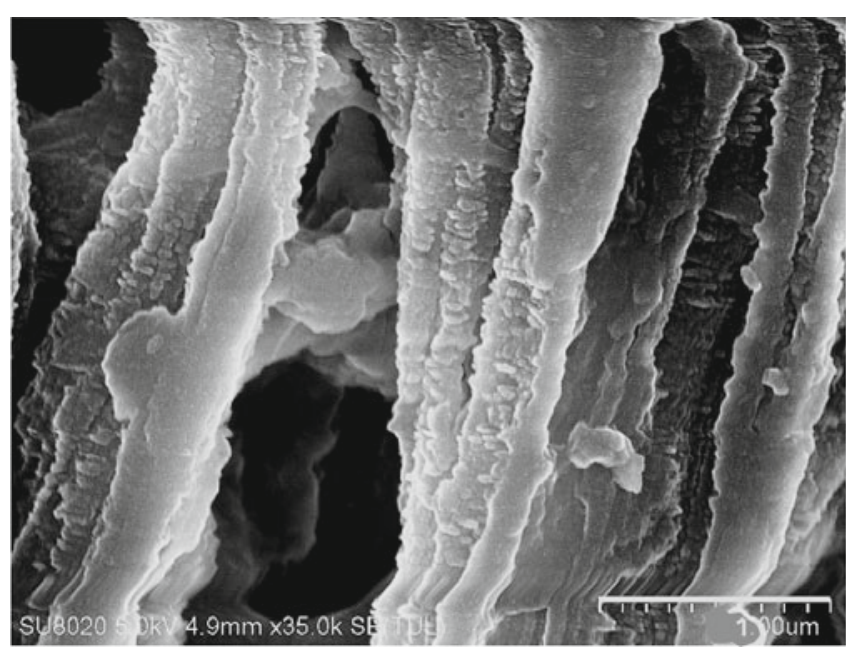

Figure 15. SEM image of membrane surface after MF1 module rinsing with $\mathrm{NaOH}$ solutions several times

\section{CONCLUSIONS}

The application of MF process with polypropylene membrane for the separation of broths, allowed to obtain a permeate with the turbidity at a level of $0.72-1.46$ NTU. Moreover, the obtained permeate was free from separated Citrobacter freundii bacteria. Therefore, the MF process can be considered as a pre-treatment method for the preparation of feed for nanofiltration and reverse osmosis, and other processes applied for the downstream processing of the post-fermented solutions.

The intensive membrane fouling during the broth filtration was confirmed by SEM observations. The fo- uling caused a decrease the permeate flux to a level of $20-30 \mathrm{~L} / \mathrm{m}^{2} \mathrm{~h}$. This efficiency can be maintained when the module is systematically rinsed with water. However, rinsing the module with water did not permit to remove all the deposits formed on the membrane surface. A continuous deposit layer, almost without the bacteria cell, was observed on the membrane surface even after long-term module rinsing with water.

The application of chemical cleaning (P3-ultrasil 11 solution) for 30 minutes also did not allow to recover the initial module efficiency. The deposit removal and clean membranes were obtained when the MF module was rinsed with a $1 \mathrm{wt} \% \mathrm{NaOH}$ solution. This confirmed that the strong alkaline media are appropriate for cleaning the membranes used for broth separation. However, the permeate flux obtained during broth filtration was similar to that when only water was used for module rinsing. Moreover, after chemical cleaning the small changes of membrane surface due to polymer degradation were observed. Therefore, in the studied batch fermentation/MF filtration system, the module should be systematically rinsed only with water, and additionally periodically with $\mathrm{NaOH}$ solution for removal an access of irreversible fouling layer.

\section{LITERATURE CITED}

1. Cui, Z.F. \& Muralidhara, H.S. (Eds.). (2010). Membrane technology. A practical guide to membrane technology and applications in food and bioprocessing. Oxford, UK: Elsevier.

2. Sadr Ghayeni, S.B., Beatson, P.J., Fane, A.J. \& Schneider, R.P. (1999). Bacterial passage through microfiltration membranes in wastewater applications. J. Membr. Sci. 153, 71-82. DOI: 10.1016/S0376-7388(98)00251-8.

3. Avci, F.G., Huccetogullari, D. \& Azbar, N. (2014). The effects of cell recycling on the production of 1,3-propanediol by Klebsiella pneumonia. Bioprocess Biosyst. Eng. 37, 513-519. DOI: $10.1007 / \mathrm{s} 00449-013-1018-z$.

4. Noworyta, A., Trusek-Holownia, A., Mielczarski, S. \& Kubasiewicz-Ponitka, M. (2006). An integrated pervaporationbiodegradation process of phenolic wastewater treatment. Desalination. 198, 191-197. DOI: 10.1016/j.desal.2006.01.025.

5. Tomczak, W. (2014). Badania rozdzielania brzeczek fermentacyjnych technikami membranowymi (Studies of broths separation by membrane processes). PhD thesis, West Pomeranian University of Technology, Szczecin.

6. Sadr Ghayeni, S.B., Beatson, P.J., Schneider, R.P. \& Fane, A.G. (1998). Water reclamation from municipal wastewater using combined microfiltration-reverse osmosis (MF-RO): Preliminary performance data and microbiological aspects of system operation. Desalination. 116, 65-80. DOI: 10.1016/ S0011-9164(98)00058-7.

7. Kumar, R. \& Ismail, A.F. (2015). Fouling control on microfiltration/ultrafiltration membranes: Effects of morphology, hydrophilicity, and charge. J. Appl. Polym. Sci. 132, 1-20. DOI: 10.1002/app.42042.

8. Bonnélye, V., Guey, L. \& Del Castillo, J. (2008). UF/MF as RO pre-treatment: the real benefit. Desalination. 222, 59-65, DOI: 10.1016/j.desal.2007.01.129.

9. Ogunbiyi, O.O., Miles, N.J. \& Hilal, N. (2008). The effects of performance and cleaning cycles of new tubular ceramic microfiltration membrane fouled with a model yeast suspension. Desalination. 220, 273-289. DOI: 10.1016/j.desal.2007.01.034.

10. Ulbricht, M., Ansorge, W., Danielzik, I., König, M. \& Schuster, O. (2009). Fouling in microfiltration of wine: The influence of the membrane polymer on adsorption of poly- 
phenols and polysaccharides. Sep. Purif. Technol. 68, 335-342, DOI: 10.1016/j.seppur.2009.06.004.

11. Markardij, A., Chen, X.D. \& Farid, M.M. (1999). Microfiltration and ultrafiltration of milk: some aspects of fouling and cleaning. Food Bioprod. Proc. 77, 107-113. DOI: $10.1205 / 096030899532394$.

12. Karasu, K., Glennon, N., Lawrence, N.D., Stevens, G.W., O'Connor, J.O., Barber, A.R., Yoshikawa, S. \& Kentish, S.E. (2010). A comparison between ceramic and polymeric membrane systems for casein concentrate manufacture, Int. J. Dairy Technol. 63, 284-289. DOI: 10.1111/j.1471-0307.2010.00582.x.

13. Schäfer, A.I., Fane, A.G. \& Waite, T.D. (Eds.). (2005). Nanofiltration: Principles and applications. Oxford, UK: Elsevier Advanced Technology.

14. Kroll, S., Treccani, L., Rezwan, K. \& Grathwohl, G. (2010). Development and characterisation of functionalised ceramic microtubes for bacteria filtration. J. Mem. Sci. 365, 447-455. DOI: 10.1016/j.memsci.2010.09.045.

15. Gryta, M., Markowska-Szczupak, A., Bastrzyk, J. \& Tomczak, W. (2013). The study of membrane distillation used for separation of fermenting glycerol solutions. J. Mem. Sci. 431, 1-8. DOI: 10.1016/j.memsci.2012.12.032.

16. Brandes, C., Treccani, L., Kroll, S. \& Rezwan, K. (2014). Gel casting of free-shapeable ceramic membranes with adjustable pore size for ultra- and microfiltration. J. Am. Ceram. Soc. 97, 1393-1401. DOI: 10.1111/jace.12877.

17. Metsoviti, M., Zeng, An-P., Koutinas, A.A. \& Papanikolaou, S. (2013). Enhanced 1,3-propanediol production by a newly isolated Citrobacter freundii strain cultivated on biodiesel-derived waste glycerol through sterile and non-sterile bioprocesses. J. Biotechnol. 163, 408-418. DOI: 10.1016/j.jbiotec.2012.11.018.

18. Ferreira, T.F., Ribeiro, R.R., Ribeiro, C.M.S., Freire, D.M.G. \& Coelho, M.A.Z. (2012). Evaluation of 1,3-Propanediol Production from Crude Glycerol by Citrobacter freundii ATCC 8090. Chem. Eng. Transac. 27, 157-162. DOI: 10.3303/ CET1227027.

19. Barbirato, F., Himmi, El H., Conte, T. \& Bories, A. (1998). 1,3-propanediol production by fermentation: An interesting way to valorize glycerin from the ester and ethanol industries, Ind. Crops Prod. 7, 281-289. DOI: 10.1016/S0926-6690(97)00059-9.

20. Colin, T. Bories, A. \& Moulin, G. (2000). Inhibition of Clostridium butyricum by 1,3-propanediol and diols during glycerol fermentation. Appl. Microbiol. Biotechnol. 54, 201-205, DOI: $10.1007 / \mathrm{s} 002530000365$.

21. Biebl, H. (1991). Glycerol fermentation of 1,3-propanediol by Clostridium butyricum. Measurement of product inhibition by use a pH-auxostat. Appl. Microbiol. Biotechnol. 35, 701-705, DOI: $10.1007 / \mathrm{BF} 00169880$.

22. Zeng, A.P., Ross, A., Biebl, H., Tag, C., Günzel, B. \& Deckwer, W.D. (1994). Multiple product inhibition and growth modeling of Clostridium butyricum and Klebsiellia pneumoniae in glycerol fermentation. Biotechnol. Bioeng. 44, 902-911. DOI: 10.1002/bit.260440806.

23. Bastrzyk, J. \& Gryta, M. (2015). Separation of postfermentation glycerol solution by nanofiltration membrane distillation system. Desalin. Water Treat. 53, 319-329. DOI: 10.1080/19443994.2013.839402.

24. Rodrigues, C., Cavaco Morão, A.I., de Pinho, M.N. \& Geraldes, V. (2010). On the prediction of permeate flux for nanofiltration of concentrated aqueous solutions with thin-film composite polyamide membranes. J. Membr. Sci. 346, 1-7. DOI: 10.1016/j.memsci.2009.08.023.

25. Wang, J.T., Chang, S.C., Chen, Y.C. \& Luh, K.T. (2000). Comparison of antimicrobial susceptibility of Citrobacter freundii isolates in two different time periods. J. Microbiol. Immunol. Infect. 33, 258-62.

26. Chaudhry, W.N., Haq, I.U., Andleeb, S. \& Qadri, I. (2014). Characterization of a virulent bacteriophage LK1 specific for Citrobacter freundii isolated from sewage water. $J$. Basic Microbiol. 54, 531-541. DOI: 10.1002/jobm.201200710.

27. Chung, J., Kang, J.S., Jurng, J.S., Jung, J.H. \& Kim, B.Ch. (2015). Fast and continuous microorganism detection using aptamer-conjugated fluorescent nanoparticles on an optofluidic platform. Biosens. Bioelectron. 67, 303-308. DOI:10.1016/j.bios.2014.08.039.

28. Bastrzyk, J., Gryta, M. \& Karakulski, K, (2014). Fouling of nanofiltration membranes used for separation of fermented glycerol solutions. Chem. Pap. 68, 757-765. DOI: 10.2478/ s11696-013-0520-8.

29. Lebleua, N., Roquesb, Ch., Aimara, P. \& Causseranda, Ch. (2009). Role of the cell-wall structure in the retention of bacteria by microfiltration membranes. J. Mem. Sci. 326, 178-185. DOI: 10.1016/j.memsci.2008.09.049.

30. Gryta, M. (2007). Influence of polypropylene membrane surface porosity on the performance of membrane distillation process. J. Membr. Sci. 287, 67-78. DOI:10.1016/j. memsci.2006.10.011.

31. Hoek, E.M.V., Bhattacharjee, S. \& Elimelech, M. (2003). Effect of membrane surface roughness on colloid-membrane DLVO interactions. Langmuir 19, 4836-4847. DOI: 10.1021/ la027083c.

32. Mohammad, A.W., Basha, R.K. \& Leo, C.P. (2010). Nanofiltration of glucose solution containing salts: Effects of membrane characteristics, organics component and salts on retention. J. Food Eng. 97, 510-518. DOI: 10.1016/j. jfoodeng.2009.11.010.

33. Xu, P., Drewes, J.E., Kim, T.U., Bellona, C. \& Amy, G. (2006). Effect of membrane fouling on transport of organic contaminants in NF/RO membrane applications, J. Membr. Sci. 279, 165-175. DOI: 10.1016/j.memsci.2005.12.001.

34. Schneider, R., Hölz, W., Wollbeck, R. \& Ripperger, S. (1988). Membranes and modules for transmembrane distillation. J. Membr. Sci. 39, 25-42. DOI: DOI:10.1016/S03767388(00)80992-8.

35. Gryta, M., Markowska-Szczupak, A., Grzechulska-Damszel, J., Bastrzyk, J. \& Waszak, M. (2014). The study of glycerolbased fermentation and broth downstream by nanofiltration, Pol. J. Chem. Technol. 16, 117-122. DOI: 10.2478/pjct-2014-0081.

36. Kosvintsev, S., Cumming, I., Holdich, R., Lloyd, D. \& Starov, V. (2004). Sieve mechanism of microfiltration separation. Coll. Surf., A: Physicochemical Engineering Aspects, 230, 167-182. DOI: 10.1016/j.colsurfa.2003.09.027.

37. Lee, D.J., Chen, G.Y., Chang, Y.R. \& Lee, K.R. (2012). Harvesting of chitosan coagulated Chlorella vulgaris using cyclic membrane filtration-cleaning. J. Taiwan Inst. Chem. Eng. 43, 948-952. DOI: 10.1016/j.jtice.2012.07.002.

38. Kim, Y.J., Yun, T., Lee, S., Kim, D. \& Kim, J. (2014). Accelerated testing for fouling of microfiltration membranes using model foulants. Desalination. 343, 113-119 DOI: 10.1016/j. desal.2014.01.016.

39. Pollice, A., Brookes, A., Jefferson, B. \& Judd, S. (2005). Sub-critical flux fouling in membrane bioreactors a review of recent literature. Desalination 174, 221-230. DOI: 0.1016/j. desal.2004.09.012. 